\title{
Relationship Between Job Autonomy and Job Stress Among Public Secondary School Principals in Punjab, Pakistan
}

\author{
Dr. Madiha Shah (Corresponding author) \\ Department of Education, University of Management and Technology \\ Lahore, Pakistan \\ Tel: 92-336-4533-625 E-mail: madihashah.phd@gmail.com \\ Azhar Haseeb \\ Department of Education, University of Management and Technology \\ Lahore, Pakistan \\ E-mail: azhar.haseeb360@gmail.com
}

Received: October 13, 2019 Accepted: November 24, 2019 Published: November 27, 2019

doi:10.5296/ijld.v9i4.15938

URL: https://doi.org/10.5296/ijld.v9i4.15938

\begin{abstract}
School principals play a dynamic role in schools' administrative processes where independent decision-making is inevitable. The present study investigates the level of job autonomy as experienced by public secondary school principals of Punjab, Pakistan. The study further determines the relationship between job autonomy and job stress among school principals. The study uses a survey research design where two scales i.e., Job Autonomy Scale by Breaugh (1985) and Organizational Stress Index by Shrivastava and Singh (1984) were used to measure job autonomy and job stress respectively. The study comprises the sample of 145 public secondary school principals, working in a district of Punjab, Pakistan. The research questions are addressed by conducting descriptive as well as inferential statistics. The study identifies a positive and moderate relationship between job autonomy and job stress among secondary school principals. It is found that school principals perceive themselves more autonomous in method autonomy and scheduling autonomy while less autonomous in criteria autonomy. The results exhibit that school principals suffered from greater stress because of low self-esteem.
\end{abstract}


The current study suggests that school principals should be provided with middle-level job autonomy to mitigate their job stress.

Keywords: Job Autonomy, Job Stress, School Principals, Secondary Schools

\section{Introduction}

School principals, in the recent years, are expected to perform an instructional as well as an administrative role. The school principals are responsible for budgeting and staffing (Khan \& Mirza, 2011) and are considered accountable for the students' academic achievement (Khan \& Shaheen, 2016) and the overall school performance (Gentilucci, 2004). Principals are required to interact with the parents of students and play a vital role in society (Constantino, 2007; Dinham, 2007; Jalongo, 2008). They are instructional leaders and responsible to ensure the professional development of their staff (Glanz, 2005; Holland, 2004).

Job autonomy refers to the degree to which an employee of an organization has the freedom in planning and scheduling work and independence in setting different strategies to perform tasks (Saragih, 2011). It is an individual's freedom to determine how to carry out the tasks, organize, and engage in work-related activities (Vansteenkiste, Zhou, Lens, \& Soenens, 2005).

Work autonomy is also considered as the working characteristic that is straightaway connected with high intrinsic motivation (Galletta, Portoghese, \& Battistelli, 2011; Humphrey, Nahrgang, \& Morgeson, 2007), better job performance (Saragih, 2011), and productive work behaviors (Langfred \& Moye, 2004). To make the employees feel more personally responsible to work, they must be provided with a considerable amount of freehand in decision-making for the accomplishment of several given tasks (Purcell, 2010). However, autonomy sometimes plays a role in the negative penalties of role ambiguity and role conflict (Langfred, 2000; Liu, Spector, Liu, \& Shi, 2011).

Job autonomy is essential not only for financial benefits, but plays a vital role in a series of consequences, such as job satisfaction (Gashi, 2013), job stress (Pearson \& Moomaw, 2005), and employee health and well-being (Thompson \& Prottas, 2006). Autonomy is one of the pertinent work characteristics that directly affect job satisfaction of personnel. Perceived job autonomy and control are positively correlated to the job satisfaction of employees (Naqvi, Ishtiaq, Kanwal, \& Ali, 2013).

Job stress, on the other hand, is one of the common problems often highlighted in the work environment (Bliese, Edwards, \& Sonnentag, 2017; Leventis, Papakitsos, Karakiozis, \& Argyriou, 2017; Yozgat, Yurtkoru, \& Bilginoglu, 2013). Alipour and Monfared (2015) defined job stress as when a person is given a job that is not well-matched with his capabilities and awareness, it can cause stress to the individual. Job stress occurs in the result of any discrepancy between demands of job or workplace and the ability of the person to fulfill those demands (Masood, 2013). Job stress for school principals has become a major problem in the recent years (Mahfouz, 2018; Sabina, 2014; Tahir et al., 2018). Lovely (2004) found in her study that school principals resign from their positions after five years on the average because of occupational stress, increased accountability, low job autonomy, and inadequate professional skills. With the rise of democracy, shared decision-making has become a global 
phenomena (Kalleberg, Nesheim, \& Olsen, 2009). Participative decision-making and employee empowerment enhances organizational commitment (Zaraket, Garios, \& Malek, 2018) and improves job satisfaction (Amarasena, Ajward, \& Haque, 2015) but it can also have some negative consequences (Kalleberg et al., 2009).

\section{Literature Review}

Job autonomy is the degree to which the job provides considerable amount of freedom, independence, as well as discretion to an individual in planning and scheduling work and in determining the procedures to be used in carrying it out (Kalleberg et al., 2009). Lack of participation in decision-making and low job autonomy causes less job satisfaction (Bhatti, \& Qureshi, 2007), decreased organizational commitment (Zaraket et al., 2018), low work engagement (Akram, Ali, \& Hassan, 2013), increased turnover (Ahuja, Chudoba, Kacmar, McKnight, \& George, 2007), and low work performance (Saragih, 2011) among employees. Job autonomy, on the other hand is positively related to job satisfaction (Rizwan et al., 2014), employee motivation (Cunningham, 2016), organizational commitment (Khan, 2016), work engagement (Lin, \& Ping, 2016), and work performance (Suteerawut, Vanno, \& Khaikleng, 2016), while job autonomy is negatively correlated with employee turnover (Rathakrishnan, Imm, \& Kok, 2016).

Stress is an adverse reaction of people towards excessive pressure regarding demands and expectations from them. It is caused when the imbalance leads towards the deterioration of psychological well-being of individual (Amato, \& Zijlstra, 2003). Job stress leads to decreased job satisfaction (Aghdasi, Kiamanesh, \& Ebrahim, 2011; Ismail, Yao, \& Yunus, 2009; Yaacob, \& Long, 2015), increased burnout (Reddy \& Poornima, 2012), poor physical and mental health of employees (Thorsteinsson, Brown, \& Richards, 2014), decreased organizational commitment (Ekienabor, 2016), increased turnover (Arshadi \& Damiri, 2013; Dysvik \& Kuvaas, 2011; Thorsteinsson et al., 2014), low productivity, and reduced work performance among employees (Appiah, \& Fynn, 2017; Ling, \& Bhatti, 2014; Yozgat et al., 2013). It is also established that major factors that contribute to job stress are workload, role conflict, role ambiguity, low participation in decision-making, and less communication with employees (Masood, 2013).

Pearson and Moomaw (2005) conducted a study to examine the relationship between teachers' job autonomy and job stress among elementary and secondary school teachers in Florida, USA. Around 300 school teachers from both the public and private schools were surveyed. The study highlighted that the teachers who feel themselves empowered and autonomous were less stressed and showed a high degree of professionalism.

Bhatti and Qureshi (2007) conducted a study to determine the relationship between job autonomy and job satisfaction taking self-efficacy as a moderator among IT workers in Malaysia. They defined job autonomy as the freedom, independence, and discretion to employees to decide their work schedules and methods and procedures. The results showed that job autonomy led to job satisfaction which consequently led to reduced occupational strain. Bhatti and Qureshi (2007) further claimed that when the employees were given autonomy, they became more self-efficacious and showed less emotional exhaustion. 
Kalleberg et al. (2009) found the effect of job autonomy on job stress among industry workers in Norway. The study used survey by telephone and face to face interviews. The results showed that employees who had a higher level of job autonomy were facing a lower level of job stress. The researchers claimed that job autonomy caused a decline in job stress.

Job autonomy causes job stress as Adebayo and Ezeanya (2011) stated that job autonomy did not have a positive effect on employees and their working environment all the time. Saragih (2011) examined the relationship between job autonomy and job stress among bank employees in Indonesia. The study was conducted using a survey design. The findings indicated that job autonomy was not significantly related to job stress. There was no effect on job stress by increasing or reducing job autonomy.

Ahari, Mehrabi, Kord, and Karimi (2013) conducted a study to identify the factors that contribute to job stress among telecommunication employees in Lorestan province, Iran. The findings of the study highlighted job autonomy as one of the major factors causing job stress. Other factors identified in their study were social, technological, family-related factors, and financial factors. Dysvik, and Kuvaas (2011) examined the relationship between job autonomy and job stress on public health officials in Norway. The researchers stated that job autonomy was negatively related to job stress, turnover intentions, and exhaustion. The study further claimed that job autonomy was negatively correlated to detrimental outcomes for example, stress and role ambiguity.

\section{Background of the Study}

The government of Pakistan founded the National Reconstruction Bureau in 1999 which gave a comprehensive local government plan also known as the "Devolution Plan". According to this plan, the Executive District Officer (EDO) was supposed to lead the education department of the district. District governments were provided with the functional responsibility of delivering elementary and secondary education at their district level. As a result, district management and community were empowered to plan, manage, mobilize, and utilize the given resources. Moreover, they were enabled to monitor and assess the educational processes (Zaidi, 2005).

After this devolution at the grass-root level, the headteachers of schools felt more autonomous in decision-making (Zaidi, 2005). Khan, and Mirza (2011) stated in their study that after implementation of the devolution plan, the headteachers became more accountable to district governments. These district governments were previously controlling most of the matters relating to academics, administration as well as managerial.

\section{Statement of the Problem}

School principals play a vital role in the education system of a country. Principals are not directly involved in instructional practices, however, they are considered as an important factor involved in student achievement (Khan \& Shaheen, 2016). They are also responsible and accountable for students' well-being (Constantino, 2007) and the professional growth of teachers (Glanz, 2005; Holland, 2004). Multiple factors are involved in making the job of school principals stressful and burdensome. The present study was conducted to investigate whether job autonomy is one of the major determinants of job stress among public secondary 
school principals.

A few studies were found in the literature which explored the association between job autonomy and job stress (Ahari et al., 2013; Bhatti \& Qureshi, 2007; Dysvik \& Kuvaas, 2011; Rizwan et al., 2014, Saragih, 2012) but none of these studies targeted school principals. The target population of those studies was mostly the employees of other sectors rather than education sector. A study addressing job autonomy and job stress among school teachers was conducted in Taiwan by Pearson, and Moomaw (2005). However, none of these studies stressed on finding the link between job autonomy and work stress among school administrators.

Moreover, previous researches on job autonomy and its relationship with job stress reported miscellaneous results. Kallberg, Neshiem, and Olsen (2009) reported a significant and inverse connection between work autonomy and job stress among industry workers in Norway. Pearson and Moomaw (2005) indicated a significant negative relationship between job autonomy and job stress among elementary and secondary school teachers in Florida. Bhatti and Qureshi (2007) stated that job autonomy leads to greater job satisfaction that consequently leads to reduced occupational stress. Saragih (2011) reported a non-significant association between autonomy at work and job stress among banking salespersons. However, on the other hand, Ahari et al. (2013) pointed out that job autonomy is positively correlated with job stress. The researchers further mentioned that job autonomy was among the major factors that cause job stress in telecommunication employees due to increased accountability (Ahari et al., 2013).

Kalleberg et al. (2009) elaborated that when employees were provided with greater work autonomy, their responsibility and accountability also increased which could result in increased job stress among them. Rizwan et al. (2014) stated that as job autonomy provides freedom and power to employees to perform their duties, it could increase job stress and emotional strain among them.

After reviewing the relevant literature, the problem arose if job autonomy is correlated with job stress among secondary school principals and if so, is this correlation positive or negative.

\section{Purpose of the Study}

The role of school principal is continuously changing and becoming increasingly complex. The present study examines the perceptions of public secondary school principals regarding their job autonomy and job stress. It further determines the relationship between job autonomy and job stress among secondary school principals. Previous researches conducted on this topic reported inconsistent results. Therefore, the current study aims to fill the gap found in the literature. It will further provide an insight into educational administrators to decide what level of job autonomy should be given to school principals to enhance their productivity and output.

\section{Research Questions}

The study intends to answer the following research questions:

1). What is the level of job autonomy among public secondary school principals of Punjab, Pakistan? 
2). What is the level of job stress among public secondary school principals of Punjab, Pakistan?

3). Is there any significant relationship between job autonomy and job stress among public secondary school principals?

\section{Conceptual Framework}

Hackman and Oldham (1976) proposed a model for job autonomy which was based on the demand-control theory. The demand-control theory emphasizes power, dependence, and social relations. According to this theory, increased power (autonomy) allows individuals greater flexibility in defining and deciding their role. Autonomy also provides discretion to employees in choosing work methods and scheduling their work (Morgeson, \& Humphrey, 2005). Job autonomy was defined as control over worker himself, control over work environment, and freedom from dependence (Bhatti, \& Qureshi, 2007). It refers to freedom in decision-making (Sabina, 2014), freedom in organization of work (Kallberg et al., 2009), and a free hand in choices (Naqvi et al., 2013).

Breaugh (1985) proposed a model of job autonomy consisting of (i) Method Autonomy, (ii) Scheduling Autonomy, and (iii) Criteria Autonomy. According to this framework, job autonomy was considered as the freedom in choosing work methods to perform a job, sequencing work activities, and independence to modify the work objectives by employees. The current study comprised of the following dimensions of job autonomy i.e., Method Autonomy, Scheduling Autonomy, and Criteria Autonomy which are widely used to measure job autonomy among employees.

Shrivastava and Singh (1984) developed a model for organizational stress consisting of the following dimensions: (i) Workload, (ii) Role Ambiguity and Role Conflict, (iii) Socio-political Pressures, (iv) Low Self-esteem, and (v) High Stake Involvement. The current study uses Shrivastava and Singh (1984) model for defining and measuring job stress among school principals.

\section{Methodology}

The study was quantitative in nature and survey design was used for the purpose of data collection. More than 300 secondary school principals were requested to complete the survey questionnaire. A total of 145 filled questionnaires were gathered for the analysis.

Job autonomy among school principals was measured by adopting a scale that was originally developed by Breaugh (1985). The questionnaire measures the three factors of job autonomy: (i) Method Autonomy, (ii) Scheduling Autonomy, and (iii) Criteria Autonomy. The questionnaire consisted of 9 items (3-items for each subscale). The internal consistency of the instrument was 0.78 .

Organizational Stress Index by Shrivastava and Singh (1984) was adapted to measure job stress. The questionnaire consisted of 46 items. The reliability coefficient alpha was reported as 0.86 for this scale. Both the questionnaires used a five-point Likert scale (strongly disagree to strongly agree). 


\section{Macrothink Institute ${ }^{\mathrm{TM}}$}

Research questions were analyzed using descriptive and inferential statistics. For descriptive analysis, frequency, percentage, mean, and standard deviation were calculated. For inferential analysis, Pearson's Correlation was used to determine the relationship between job autonomy and job stress.

\section{Results and Findings}

Scheduling Autonomy was found to be higher $(\mathrm{M}=4.35, \mathrm{SD}=.42)$ among the three types of autonomy (Table 1). Majority of the respondents agreed with the statement, "I have some control over the sequencing of my work activities" $(\mathrm{M}=4.41, \mathrm{SD}=.520)$. The school principals perceived to practice Method Autonomy at the middle level $(\mathrm{M}=4.28, \mathrm{SD}=.55)$. A large number of school principals agreed that they were free to choose the work methods to perform their duties $(\mathrm{M}=4.34, \mathrm{SD}=.679)$. What the school principals practiced less was the Criteria Autonomy $(\mathrm{M}=4.10, \mathrm{SD}=.45)$. More than $30 \%$ of the school principals did not agree with the statement, "I am able to modify what my job objectives are" $(\mathrm{M}=3.88, \mathrm{SD}=.618)$ making Criteria Autonomy at a lowest level.

Table 1. Mean and Standard Deviation of Subscales of Job Autonomy $(N=145)$

\begin{tabular}{lcc}
\hline Variables & Mean & SD \\
\hline Method Autonomy & 4.28 & .55 \\
Scheduling Autonomy & 4.35 & .42 \\
Criteria Autonomy & 4.10 & .45 \\
\hline
\end{tabular}

Table 2 shows that the mean values of subscales of job stress. Public secondary school principals perceived themselves to be suffered from stress caused by Low Self-esteem $(\mathrm{M}=$ 4.01, $\mathrm{SD}=.52)$ and job stress due to Role Ambiguity and Role Conflict $(\mathrm{M}=3.99, \mathrm{SD}=.56)$ at the higher level. The participants responded that they get fewer salaries in comparison to their workload. The school principals felt that they were rarely rewarded for their hard work and performance. Principals perceived that their officers often gave them contradictory instructions regarding their work. The principals stated that most of the time, they were not clear what type of work behavior the higher authorities expected of them. Secondary school principals suffered from job stress caused by excessive Workload $(\mathrm{M}=3.85, \mathrm{SD}=.68)$ and Socio-political Pressures $(\mathrm{M}=3.81, \mathrm{SD}=.65)$ at medium level. The principals perceived that they were compelled to violate the formal procedures and policies because of the political pressures. The least contributing factor to job stress among school principals was High Stake Involvement (M $=3.76, \mathrm{SD}=.56$ ). 


\section{Macrothink}

Table 2. Mean and Standard Deviation of Subscales of Job Stress $(N=145)$

\begin{tabular}{llc}
\hline Variables & Mean & SD \\
\hline Job Stress due to Workload & 3.85 & .68 \\
Job Stress due to Role Ambiguity and Role Conflict & 3.99 & .56 \\
Job Stress due to Socio-political Pressures & 3.81 & .65 \\
Job Stress due to Low Self-esteem & 4.01 & .52 \\
Job Stress due to High Stake Involvement & 3.76 & .56 \\
\hline
\end{tabular}

Table 3 shows that a significant correlation exists between Criteria Autonomy and Work Stress due to High Stake Involvement $(r=.585, p<.000)$ as well as between Criteria Autonomy and Role Ambiguity and Role Conflict $(r=.544, p<.000)$. A significant but moderate relationship is found between Criteria Autonomy and Job Stress due to Socio-political Pressure $(r=.532, p$ $<.000)$, Criteria Autonomy and Job Stress due to Workload $(r=.495, p<.000)$, Criteria Autonomy and Job Stress due to Low Self-esteem $(r=.455, p<.000)$. Similarly, a significant and moderate relationship is found between Scheduling Autonomy and Job Stress due to Low Self-esteem $(r=.447, p<.000)$. However, a weak relationship exists between Method Autonomy and Job Stress due to High Stake Involvement $(r=.384, p<.000)$.

The findings of the study indicated a positive and moderate relationship between job autonomy and job stress. Previous researchers have reported inconsistent results related to the problem. The results of the current study are supported by the previous researches (Abedayo, \& Ezeanya, 2011; Ahari et al., 2013; Rizwan et al., 2014). Kalleberg et al. (2009) researched in Norway and reported similar results. Participation and control over a job is not always effective for workers. With a rise in job autonomy, responsibility and accountability also increase which ultimately leads towards increased job stress. Public secondary school principals practiced greater autonomy and suffered from greater job stress. 
Table 3. Pearson's Correlation among Variables $(\mathrm{N}=145)$

\begin{tabular}{|c|c|c|c|c|c|c|c|c|}
\hline & MA & SA & $\mathrm{CA}$ & WLD & RARC & SPP & LSE & HSI \\
\hline \multirow[t]{2}{*}{ MA } & 1 & $.589^{* *}$ & $.343^{* *}$ & $.373^{* *}$ & $.287^{* *}$ & $.258^{* *}$ & $.361^{* *}$ & $.384^{* *}$ \\
\hline & & .000 & .000 & .000 & .000 & .002 & .000 & .000 \\
\hline \multirow[t]{2}{*}{ SA } & & 1 & $.348^{* *}$ & $.176^{*}$ & $.329^{* *}$ & $.191^{*}$ & $.447^{* *}$ & $.305^{* *}$ \\
\hline & & & .000 & .034 & .000 & .021 & .000 & .000 \\
\hline \multirow[t]{2}{*}{ CA } & & & 1 & $.495^{* *}$ & $.544^{* *}$ & $.532^{* *}$ & $.455^{* *}$ & $.585^{* *}$ \\
\hline & & & & .000 & .000 & .000 & .000 & .000 \\
\hline \multirow[t]{2}{*}{ WLD } & & & & 1 & $.719^{* *}$ & $.695^{* *}$ & $.647^{* *}$ & $.656^{* *}$ \\
\hline & & & & & .000 & .000 & .000 & .000 \\
\hline \multirow[t]{2}{*}{ RARC } & & & & & 1 & $.775^{* *}$ & $.819^{* *}$ & $.761^{* *}$ \\
\hline & & & & & & .000 & .000 & .000 \\
\hline \multirow[t]{2}{*}{ SPP } & & & & & & 1 & $.711^{* *}$ & $.723^{* *}$ \\
\hline & & & & & & & .000 & .000 \\
\hline \multirow[t]{2}{*}{ LSE } & & & & & & & 1 & $.746^{* *}$ \\
\hline & & & & & & & & .000 \\
\hline HSI & & & & & & & & 1 \\
\hline
\end{tabular}

**. Correlation is significant at the level 0.01 (2-tailed).

$\mathrm{MA}=$ Method Autonomy, $\mathrm{SA}=$ Scheduling Autonomy, $\mathrm{CA}=$ Criteria Autonomy, WLD $=$ Workload, RARC $=$ Role Ambiguity and Role Conflict, SPP $=$ Socio-political Pressures, LSE $=$ Low Self-esteem, HSI = High Stake Involvement.

\section{Discussion, Implications, Recommendations, and Conclusion}

The findings of the study were compatible with the previous researches (Abedayo, \& Ezeanya, 2011; Ahari et al., 2013; Kalleberg et al., 2009; Rizwan et al., 2014) but were contrary to some studies which argued that job autonomy was inversely related to job stress (Dysvik, \& Kuvaas, 2011; Bhatti, \& Qureshi, 2007; Pearson, \& Moomaw, 2005). These studies reported that with a rise in job autonomy of employees, job stress decreases. The findings of the current study can be justified in a manner that when the employees are provided with greater autonomy, the 
organizations require them to own greater responsibility in enhancing their productivity both at an individual and organizational level. Consequently, this phenomenon causes an increase in job stress. They feel themselves as more accountable and higher expectations from their bosses make them feel more stressful. A larger degree of job autonomy may enhance the pressure and intensity of work. It is named as "Responsible Autonomy" which means being more autonomous increases work responsibility that may cause increased job stress. Sense of being answerable to the boss or someone superior is likely to cause job stress among employees (Malik, Danish, \& Munir, 2012).

The findings of the study revealed that the school principals should be provided with mid-level job autonomy as increased independence in work related decisions intensify stress among personnel. When principals perceive themselves as more autonomous, they feel more responsible and accountable to the higher authorities. The statistics revealed that secondary school principals have suffered the most from job stress due to low self-esteem and job stress due to role ambiguity and role conflict.

The present study was conducted by using self-reported questionnaires to measure perceived job autonomy and job stress among principals. Self-reported questionnaires can cause response bias. Due to limited time and resources, the study was confined to a single district of Punjab and the sample size was small. Future research may be conducted with comparatively increased sample size in order to make effective generalizations. Closed-ended questionnaires were used to gather data only from public secondary school principals. The results might have been different in case of private sector schools. Moreover, the researchers should consider exploring the other causes of job stress among school principals. The administrators and higher authorities should strategize to improve the lifestyle and social status of principals to guard their self-esteem. Seminars, workshops, and training should be conducted for school principals to cope with their occupational hazards. The principals themselves should also consider responsibility and accountability as part-of-procedure and not a threat to their jobs. This would surely mitigate their occupational stress.

\section{References}

Adebayo, S. O., \& Ezeanya, I. D. (2011). Task identity and job autonomy as correlates of burnout among doctors in Jos. Journal of Basic and Applied Scientific Research, 1(7), 644-648.

Aghdasi, S., Kiamanesh, A. R., \& Ebrahim, A. N. (2011). Emotional Intelligence and organizational commitment: testing the mediatory role of occupational stress and job satisfaction. Procedia-Social and Behavioral Sciences, 29, 1965-1976. https://doi.org/10.1016/j.sbspro.2011.11.447

Ahari, M. B., Mehrabi, J., Kord, K., \& Karimi, F. (2013). Studying the relation of job stress with job satisfaction and organizational productivity among the telecommunications employees in lorestan province. Interdisciplinary Journal of Contemporary Research in Business, 5(1), 42-57. 


\section{Macrothink}

International Journal of Learning and Development

ISSN 2164-4063 2019, Vol. 9, No. 4

Ahuja, M. K., Chudoba, K. M., Kacmar, C. J., McKnight, D. H., \& George, J. F. (2007). IT Road Warriors: Balancing Work-Family Conflict, Job Autonomy, and Work Overload to Mitigate Turnover Intentions. Management Information Systems Quarterly, 31(1), 1-17. https://doi.org/10.2307/25148778

Akram, A., Ali, M., \& Hassan, M. (2013). Impact of job autonomy on work engagement: The mediating role of job crafting in universities of Pakistan. International Journal of Management Sciences and Business Research, 3(1), 31-44.

Alipour, F., \& Monfared, M. (2015). Examining the relationship between job stress and organizational commitment among nurses of Hospitals. Journal of Patient Safety \& Quality Improvement, 3(4), 277-280.

Amarasena, S. M., Ajward, A. R., \& Haque, A. A. (2015). The Effects of Demographic Factors on Job Satisfaction of University Faculty Members in Sri Lanka. International Journal of Academic Research and Reflection, 3(4), 89-106.

Amato, A., \& Zijlstra, F. R. (2003). Occupational stress: A review of the literature relating to mental health. Stress Impact. Surrey: University of Surrey.

Appiah, W., \& Fynn, I. (2017). The Impact of Occupational Stress on Employee's Performance: A Study at Twifo Oil Palm Plantation Limited. African Journal of Applied Research (AJAR), 3(1), 14-25.

Arshadi, N., \& Damiri, H. (2013). The relationship of job stress with turnover intention and job performance: Moderating role of OBSE. Procedia-Social and Behavioral Sciences, 84, 706-710. https://doi.org/10.1016/j.sbspro.2013.06.631

Bhatti, K., \& Qureshi, T. (2007). Impact of employee participation on job satisfaction, employee commitment, and employee productivity. International Review of Business Research Papers, 3(2), 54-68.

Bliese, P. D., Edwards, J. R., \& Sonnentag, S. (2017). Stress and well-being at work: A century of empirical trends reflecting theoretical and societal influences. Journal of Applied Psychology, 102(3), 389-402. https://doi.org/10.1037/ap10000109

Breaugh, J. A. (1985). The measurement of work autonomy. Human Relations, 38(6), 551-570. https://doi.org/10.1177/001872678503800604

Constantino, S. M. (2007). Keeping parents involved through high school. The Education Digest, 73(1), 57-61.

Cunningham, A. (2016). What are the key drivers used to promote employee motivation and engagement in a manufacturing environment? Retrieved from: http://digitalcommons.ilr.cornell.edu/student/106

Dinham, S. (2007). How schools get moving and keep improving: Leadership for teacher learning, student success and school renewal. Australian Journal of Education, 51(3), 263-275. https://doi.org/10.1177/000494410705100304 
Dysvik, A., \& Kuvaas, B. (2011). Intrinsic motivation as a moderator on the relationship between perceived job autonomy and work performance. European Journal of Work and Organizational Psychology, 20(3), 367-387. https://doi.org/10.1080/13594321003590630

Ekienabor, E. E. (2016). Impact of Job Stress on employees' productivity and commitment. International Journal for Research in Business, 2(5), 124-134.

Galletta, M., Portoghese, I., \& Battistelli, A. (2011). Intrinsic motivation, job autonomy and turnover intention in the Italian healthcare: The mediating role of affective commitment. Journal of Management Research, 3(2-E3), 1-19. https://doi.org/10.5296/jmr.v3i2.619

Gashi, M. (2013). The Influence of Work Overload and Autonomy on Job Satisfaction, Organizational Commitment and Turnover Intent: The Case of Kosovo. Human Resource Studies, 6(1), 18-40.

Gentilucci, J. L. (2004). Improving school learning: The student perspective. The Educational Forum, 68(2), 133-143. https://doi.org/10.1080/00131720408984620

Glanz, J. (2005). What every principal should know about instructional leadership. Thousand Oaks, CA: Corwin Press.

Hackman, J. R., \& Oldham, G. R. (1976). Motivation through the design of work: Test of a theory. Organizational Behavior and Human Performance, 16(2), 250-279. https://doi.org/10.1016/0030-5073(76)90016-7

Holland, P. (2004). Principals as supervisors: A balancing act. NASSP Bulletin, 88(639), 3-14. https://doi.org/10.1177/019263650408863902

Humphrey, S. E., Nahrgang, J. D., \& Morgeson, F. P. (2007). Integrating motivational, social, and contextual work design features: A meta-analytic summary and theoretical extension of the work design literature. Journal of Applied Psychology, 92, 1332-1356. https://doi.org/10.1037/0021-9010.92.5.1332

Ismail, A., Yao, A., \& Yunus, N. K. Y. (2009). Relationship between Occupational Stress and Job Satisfaction: An Empirical Study in Malaysia. Romanian Economic Journal, 12(34), 3-30.

Jalongo, M. R. (Ed.). (2008). Enduring bonds: The significance of interpersonal relationships in young children's lives (Vol. 1). Springer Science \& Business Media. https://doi.org/10.1007/978-0-387-74525-1

Kalleberg, A. L., Nesheim, T., \& Olsen, K. M. (2009). Is participation good or bad for workers? Effects of autonomy, consultation and teamwork on stress among workers in Norway. Acta Sociologica, 52(2), 99-116. https://doi.org/10.1177/0001699309103999

Khan, A. M., \& Mirza, M. S. (2011). Implementation of decentralization in education in Pakistan: Framework, status and the way forward. Journal of Research and Reflections in Education, 5(2), 146 -169.

Khan, M., \& Shaheen, A. (2016). The leadership role of secondary school principals and its 
impact on students' academic achievement. FWU Journal of Social Sciences, 10(1), 75-80.

Khan, S. K. (2016). Study of organisation citizenship behaviour, job autonomy and organisational resources towards organisation commitment in private schools in Malaysia. International Academic Research Journal of Social Science, 2(1), 42-48.

Langfred, C. W. (2000). The paradox of self-management: Individual and group autonomy in work groups. Journal of Organizational Behavior, 21(5), 563-585. https://doi.org/10.1002/1099-1379(200008)21:5<563::AID-JOB31>3.0.CO;2-H

Langfred, C. W., \& Moye, N. A. (2004). Effects of task autonomy on performance: An extended model considering motivational, informational, and structural mechanisms. Journal of Applied Psychology, 89, 934-945. https://doi.org/10.1037/0021-9010.89.6.934

Leventis, C., Papakitsos, E. C., Karakiozis, K., \& Argyriou, A. (2017). Work-related stress and burnout factors of principals in Regional Greece: A historical perspective. Journal of Research Initiatives 3(1), 1-11.

Lin, J., \& Ping, N. (2016). Perceived job autonomy and employee engagement as predictors of organizational commitment. Undergraduate Journal of Psychology, 29(1), 1-12.

Ling, S. M., \& Bhatti, M. A. (2014). Work Stress and Job Performance in Malaysia Academic Sector: Role of Social Support as Moderator. British Journal of Economics, Management \& Trade, 4(12), 1986-1998. https://doi.org/10.9734/BJEMT/2014/12098

Liu, C., Spector, P. E., Liu, Y., \& Shi, L. (2011). The interaction of job autonomy and conflict with supervisor in China and the United States: A qualitative and quantitative comparison. International Journal of Stress Management, 18(3), 222-245. https://doi.org/10.1037/a0024752

Lovely, S. (2004). Staffing the principalship: Finding, coaching, and mentoring school leaders. Association for Supervision and Curriculum Development (ASCD), North Beauregard Street, Alexandria.

Mahfouz, J. (2018). Principals and stress: Few coping strategies for abundant stressors. Educational Management Administration and Leadership. https://doi.org/10.1177/1741143218817562

Malik, E., Danish, R., \& Munir, Y. (2012). The impact of pay and promotion on job satisfaction: Evidence from higher education institutes of Pakistan. American Journal of Economics, Special Issue, 6-9. https://doi.org/10.5923/j.economics.20120001.02

Masood, A. (2013). Effects of job stress on employee retention: A study on banking sector of Pakistan. International Journal of Scientific and Research Publications, 3(9), 1-8.

Morgeson, F. P., \& Humphrey, M. A. (2005). The importance of job autonomy, cognitive ability, and job-related skill for predicting role breadth and job performance. Journal of Applied Psychology, 90(2), 399-406. https://doi.org/10.1037/0021-9010.90.2.399

Naqvi, S. R., Ishtiaq, M., Kanwal, N., \& Ali, M. (2013). Impact of job autonomy on 
organizational commitment and job satisfaction: The moderating role of organizational culture in fast food sector of Pakistan. International Journal of Business and Management, 8(17), 92-102. https://doi.org/10.5539/ijbm.v8n17p92

Pearson, L. C., \& Moomaw, W. (2005). The relationship between teacher autonomy and stress, work satisfaction, empowerment, and professionalism. Educational Research Quarterly, 29(1), 38-54.

Purcell, J. (2010). Building Employee Engagement. ACAS Policy Discussion Paper, London: ACAS.

Rathakrishnan, T., Imm, N. S., \& Kok, T. K. (2016). Turnover intentions of lecturers in private universities in Malaysia. Pertanika Journal of Social Sciences \& Humanities, 24(S), 129-146.

Reddy, G. L., \& Poornima, R. (2012). Occupational stress and professional burnout of University teachers in South India. International Journal of Educational Planning \& Administration, 2(2), 109-124.

Rizwan, M., Jamil, I., Shahid, U., Saeedi, A., Islam, Z., Qadeer, A., \& Mateen, A. (2014). The impact of the job stress, job autonomy and working conditions on employee satisfaction. International Journal of Human Resource Studies, 4(2), 196-207. https://doi.org/10.5296/ijhrs.v4i2.5907

Sabina, L. L. (2014). Factors influencing elements of stress and autonomy and control among school administrators (Doctoral dissertation, University of Pittsburgh, Russia).

Saragih, S. (2011). The effects of job autonomy on work outcomes: Self-efficacy as an intervening variable. International Research Journal of Business Studies, 4(3), 203-215. https://doi.org/10.21632/irjbs.4.3.203-215

Shrivastava, A. K., \& Singh, A. P. (1984). Manual of the Occupational Stress Index. (Department of Psychology, Banaras University, Varanasi).

Suteerawut, N., Vanno,V., \& Khaikleng, P. (2016). Effects of job autonomy and positive psychological capital on job performance of banking employees: Mediating role of intrinsic work motivation. The Asian Conference on Psychology and the Behavioral Sciences, Official Conference Proceedings.

Tahir, L. M., Khan, A., Musah, M. B., Ahmad, R., Daud, K., \& Al-Hudawi, S. H. V. (2018). Administrative stressors and Islamic coping strategies among Muslim primary principals in Malaysia: A mixed method study. Community Mental Health Journal, 54(5), 649-663. https://doi.org/10.1007/s10597-017-0206-8

Thompson, C. A., \& Prottas, D. J. (2006). Relationships among organizational family support, job autonomy, perceived control, and employee well-being. Journal of Occupational Health Psychology, 11, 100-118. https://doi.org/10.1037/1076-8998.10.4.100

Thorsteinsson, E. B., Brown, R. F., \& Richards, C. (2014). The relationship between 


\section{Macrothink}

International Journal of Learning and Development

ISSN 2164-4063 2019, Vol. 9, No. 4

work-stress, psychological stress and staff health and work outcomes in office workers. Psychology, 5(10), 1301-1311. https://doi.org/10.4236/psych.2014.510141

Vansteenkiste, M., Zhou, M., Lens, M., \& Soenens, B. (2005). Experiences of autonomy and control among Chinese learners: Vitalizing or immobilizing? Journal of Educational Psychology, 97, 468-483. https://doi.org/10.1037/0022-0663.97.3.468

Yaacob, M., \& Long, C. S. (2015). Role of occupational stress on job satisfaction. Mediterranean Journal of Social Sciences, 6(2, S1), 81-87. https://doi.org/10.5901/mjss.2015.v6n2s1p81

Yozgat, U., Yurtkoru, S., \& Bilginoğlu, E. (2013). Job stress and job performance among employees in public sector in Istanbul: examining the moderating role of emotional intelligence. Procedia-Social and behavioral sciences, 75, 518-524. https://doi.org/10.1016/j.sbspro.2013.04.056

Zaidi, S. A. (2005). The political economy of decentralisation in Pakistan. Transversal theme: "Decentralisation and Social Movements", Working Paper No. 1, The Swiss National Centre of Competence in Research (NCCR) North-South, Switzerland.

Zaraket, W., Garios, R., \& Malek, L. A. (2018). The impact of employee empowerment on the organizational commitment. International Journal of Human Resource Studies, 8(3), 284-299. https://doi.org/10.5296/ijhrs.v8i3.13528

\section{Copyright Disclaimer}

Copyright for this article is retained by the author(s), with first publication rights granted to the journal.

This is an open-access article distributed under the terms and conditions of the Creative Commons Attribution license (http://creativecommons.org/licenses/by/4.0/). 